\title{
Virtual palaeontology
}

David Penney

Acta Palaeontologica Polonica 59 (1), 2014: 146-146 doi: http://dx.doi.org/10.4202/app.2014.1000

Mark Sutton, Imran Rahman, and Russell Garwood 2014. Techniques for Virtual Palaeontology. 200 pp. Wiley Blackwell. Hardcover. ISBN: 978-1-118-59113-0. Price $£ 75.00 / € 90.00$; also available as an e-book (price: $£ 23.99 / € 28.99$ ).

David Penney [david.penney@manchester.ac.uk], Faulty of Life Sciences, University of Manchester, Oxford Road, Manchester M13 9PL, UK.

This is an open-access article distributed under the terms of the Creative Commons Attribution License (for details please see creativecommons.org), which permits unrestricted use, distribution, and reproduction in any medium, provided the original author and source are credited.

Forif Full text $(66.3 \mathrm{kB})$ 